\title{
The Legal Protection for Female Workers in the Perspective of Islamic Law and Law No. 11 Year 2020 on Job Creation
}

\section{| Ismail Koto ${ }^{1, *}$ | Ida Hanifah² |}

${ }^{1,2}$ Faculty of Law, Universitas Muhammadiyah Sumatera Utara, Indonesia

*ismailkoto@umsu.ac.id

\begin{abstract}
On Monday, 5 October 2020, the Draft Law on Job Creation was ratified by the House of Representatives of the Republic of Indonesia and the manuscript was signed by the government on November 3, 2020. Therefore, since November 3, 2020, the Draft Law on Job Creation promulgated in Law Number 11 Year 2020 on Job Creation. Based on the existing official text, the researcher intended to compare the rights of female workers as regulated in Law Number 13 of 2003 on Manpower with Law Number 11 of 2020 on Job Creation. The research method used in this study was a normative juridical research, with a statutory and conceptual approach, descriptive analytical research specifications, data collection by literature study, and qualitative data analysis. The protection of female workers as referred to in the previous labor law was still valid and was not discussed at all in Law Number 11 of 2020 on Job Creation. Therefore, it could be ascertained that the refusal of workers during the process of the Draft Law on Job Creation is wrong. The article which was amended related to the protection of female workers did not change the substance of the protection of female workers as previously regulated through Law Number 13 Year 2003 on Manpower. The Qur'an has been explained that people need to provide special rights for female workers. Explicitly, there is no verses in the Qur'an that mentioned the word 'special rights for female workers'. However, implicitly, there were general arguments based on the verses in the Qur'an that could be used as a basis for granting this right. Some of the special rights of female workers were implicitly communicated in Islamic teachings.

KEYWORDS

Job creation; Islamic law; female workers
\end{abstract}

\section{INTRODUCTION}

Humans are creatures who are responsible for life, both individuals and groups, can live properly on earth, this is the creator of the vast earth bestowed by God the creator. ${ }^{1}$ Human rights are basic rights inherent in humans by nature that are universal. Therefore, human rights must be secured, guarded, and ought to not be overlooked, decreased, or taken absent by anybody. The requirement of human rights is an unbroken interface within the standards of vote based system. The requirement of human rights is an unbroken interface within the standards of vote based system, the rule of law, and people's sovereignty. Therefore, it is impossible to realize a democratic and sovereign government without upholding human rights.

\footnotetext{
${ }^{1}$ Lalu Husni, Penyelesaian Perselisihan Hubungan Industrial Melalui Pengadilan Dan Di Luar Pengadilan (Jakarta: PT. Raja Grafindo, 2004).
} 
In human life, the development of human life will seek a decent life and freedom to achieve a life that exceeds expectations. Even the state provides life and work according to the 1945 Constitution which stipulates that everyone should have fun. When looking for a life that suits their own needs, interaction between humans is also expected to create a life together and provide physical life for the family. In the field of human resources, the term employment relationship involves employers and workers/labourers. In this relationship there is communication between workers and employers, which allows the company to actively participate in its activities. ${ }^{2}$

End of all shapes of segregation against ladies is part of upholding human rights. In order to ensure the enforcement of these human rights, the issue that must be considered is the existence of employers who discriminate and do not pay attention to the rights of these female workers. In the discussion of the Draft Law on Job Creation by the government and the House of Representatives of the Republic of Indonesia, it was reported that they intended to revise women's rights in Law Number 13 Year 2003 on Manpower. For example, the information that circulated during the discussion process of the bill that was conveyed by the President of the Confederation of Indonesian Trade Unions, namely menstrual leave to maternity leave which was threatened was not given according to the applicable legal provisions. ${ }^{3}$

The omnibus law became a hot topic of discussion after President Joko Widodo (Jokowi) conveyed the term on October 20, 2019. The President conveyed his plan to implement the Omnibus law as an effort to overcome regulatory obstacles in development at the People's Consultative Assembly plenary session. ${ }^{4}$ The issue continued to circulate until it became one of the reasons for the workers' rejection of the Draft Law on Job Creation. Although the government has repeatedly clarified the untruth of the information. Furthermore, in the end, on October 5, 2020 the Draft Law on Job Creation was ratified by the House of Representatives of the Republic of Indonesia and the manuscript was signed by the government on November 03, 2020. Therefore, since November 3, 2020, the Draft Law on Job Creation was promulgated in Law Number 11 Year 2020 on Job Creation. Based on the existing official text, the researcher intends to compare the rights of female workers as regulated in Law Number 13 Year 2003 on Manpower with Law Number 11 Year 2020 on Job Creation.

The history of Islamic law, labor is all efforts and endeavors made by members of the body or mind to get a proper reward. Including all types of work done physically and mentally. Labor as a factor of production has a great meaning. Because all natural wealth is useless if it is not exploited by humans and processed by labor. Many countries in East Asia, Middle East, Africa and South America are rich in natural resources but because they have not been able to explore them they remain poor and underdeveloped. Someone once said about India-Pakistan. It is a rich country inhabited by poor people, therefore besides the existence of natural resources there must also be people who are willing to work seriously, diligently and wisely in order to be able to explore natural resources for their interests. ${ }^{5}$ It is interesting to discuss how then the views of Islamic law are related to female workers.

\footnotetext{
${ }^{2}$ Lalu Husni.

${ }^{3}$ Lalu Husni.

${ }^{4}$ Christina Aryani, 'Reformulasi Sistem Pembentukan Peraturan Perundang-Undangan Melalui Penerapan Omnibus Law', Jurnal USM Law Review, 4.1 (2021), 29.

${ }^{5}$ Miftahul Rohmah, 'Perlindungan Hukum Terhadap Tenaga Kerja Perempuanmenurut Undang-Undang Nomor 13 Tahun 2003 Tentang Ketenagakerjaan Dan Hukum Islam', Fakultas Syari'ah Universitas Islam Negeri Sulthan Thaha Saifuddin Jambi, 2020.
} 
Previous research conducted by Andre Bagus Saptra (Student of the Faculty of Law, Islamic University of Indonesia). This article has been published in the Opinion rubric, International Law of the Sea Legaltalk, Legal Bulletin, Vol. 2 No. 7, 2021, September 2021. The conclusion of this research is that the fact that Indonesia has ratified the Convention on the Elimination of All Forms of Discrimination Against Women (CEDAW) seems to be forgotten. Which can be seen in the provision of the regional minimum wage which is used as a standard for male workers with single living counts who have different needs from female workers. ${ }^{6}$

Furthermore, related to the research discussed by the same research researcher, Miftahul Rohmah examined the title of legal protection of female workers according to law number year on employment and Islamic law. The results of the research above. The results of the research obtained. The legal protection of labor in the Articles of Law number year states that if the female workers/labourers referred to in the paragraph are employed between 1 p.m. and 8 p.m., then the person who is responsible is the entrepreneur. Seeing from these provisions, it is clear that every female worker/labor is entitled to legal protection. One aspect of legal protection for workers is in the form of: Economic protection, namely the protection of workers in the form of sufficient income, social protection. ${ }^{7}$

The next research that discusses related to the author's title in this research was made by Febri Jaya, with the title of ensuring the rights of female specialists after the modification of the labor law within the omnibus law, the conclusion that can be drawn from this inquire about is that the rights that are the protest of open showings are not completely genuine. The enormous and organized dispersal of wrong data has led to mistaken assumptions within the community. So there was a show of dismissal of the Omnibus Law, one of which was the security of female specialists within the Labor Cluster. Although the certification of the requirement of women's rights ought to be reaffirmed within the modification of the law, such as the obligation to grant female workers' rights to Small and Micro Enterprises which is quite often neglected.

This study wants to complement the discussion that has not been raised in previous research. So in the view that it is important to conduct research related to legal protection for female workers in terms of Islamic law and Law No. 11 Year 2020 on Job Creation.

\section{RESEARCH METHODS}

The method applied in a study is the main key to assessing the merits of a study. The method that determines the flow of activities, ranging from data hunting to concluding a truth obtained in the research. ${ }^{8}$ While legitimate investigate could be a handle to discover the run the show of law, legal principles, and legitimate tenets in arrange to reply the content of the law at hand. ${ }^{9}$ Meanwhile, according to Soekanto, ${ }^{10}$ legal investigate could be a logical movement based on certain strategies, systematics and contemplations that point to ponder one or a few certain lawful wonders, by analyzing them.

The method used in this article is a normative juridical research method that uses data sources, namely primary data in the form of related laws and regulations, secondary data is examining materials derived from journals and books, and then tertiary data is in the form

\footnotetext{
${ }^{6}$ Andre Bagus Saputra, 'Perlindungan Pekerja Perempuan Masa Pandemi Dalam Prespektif CEDW', Rubrik Opini, Hukum Laut Internasional LEGALTALK, Buletin Hukum, 2.7 (2021), 3.

${ }^{7}$ Miftahul Rohmah.

${ }^{8}$ T. A. Siregar, Metodologi Penelitian Hukum Penulisan Skripsi. Medan: Pustaka Bangsa Press (Medan: Pustaka Bangsa Press, 2005).

${ }^{9}$ P. M. Marzuki, Penelitian Hukum. Jakarta: Kencana, 2011.

${ }^{10}$ S. and S. M. Soekanto, Penelitian Hukum Normatif. Suatu Tinjauan Singkat. (Jakarta: Raja Grafindo Persada, 2003).
} 
of studying magazines, dictionaries, as well as newspapers. Considering that this article is normative, this article is analytical prescriptive. This type of research uses normative egitimate inquire about strategies (regulating juridical) or moreover called library law investigate, namely legal research conducted by examining library materials or mere secondary data. Legal research with the type of normative legal research is intended to obtain comprehensive data and information that is normative both from primary, secondary, and tertiary legal materials (Harisman, 2020).

\section{RESULTS AND DISCUSSION}

The Legal Provisions for Female Workers according to Law No. 13 Year 2003 on Manpower

Potential female workers are in the most difficult position, this can happen, among others, due to the still strong patriarchal culture, even though the issues of gender equality, rights and freedom to develop themselves have been known and circulated in the midst of society, but however, there are still discriminatory practices. Opinions that think men are superior figures in all respects are still widely found and even exist in the world of work. One of the negative effects of the opinion that men are superior is the dominance of acceptance and strategic position for the male workforce. This hinders the female workforce from developing themselves.

The above conditions are very contrary to Article 5 and Article 6 of Law No. RI. 13 of 2003 which regulates that every worker has the same opportunity without segregation to get a job. ${ }^{11}$ Each specialist has the proper to get break even with treatment without boss separation (Article 6). Another phenomenon that is no less complicated for women in finding work is the weak application of legal protection for female workers. ${ }^{12}$ Even though there is already a workers' organization that specifically accommodates all forms of workers' interests in the world of work, by some parties it is considered not optimal in carrying out its functions, including in terms of protection of female workers. This is further exacerbated by the still weak ability and personal knowledge of female workers about their rights. While on the other hand there are irresponsible people who take advantage of this ignorance and ignore existing regulations. The main cause is the existence of power and economic inequality as well as widespread misconceptions in society, where the position of men is considered to be higher than that of women. This view then justifies the idea that the female body is a sexual object.

Legal protection is defined as a series of actions in the form of guarantees to legal subjects, in an effort to provide certainty and rule of law. So it is hoped that the workforce can avoid the actions of entrepreneurs who violate the law and are irresponsible. In addition, it is undeniable that the participation of workers in national development is important, accompanied by various challenges and risks it faces. In order to provide legal protection, specifically in Law no. 13 of 2003 in the general explanation section states: Legal protection for workers, including security of workers' essential rights to arrange with bosses, assurance of word related security and wellbeing, uncommon assurance for female specialists, children, and people with incapacities, as well as security with respect to compensation, welfare, and social security of laborers.

With the Law no. 13 of 2003, according to Kusmana, actually does not only provide protection for individual rights, but also protects the rights of the community, which creates obligations. 2 So legal protection for workers does not only prioritize individualism

\footnotetext{
${ }^{11}$ Andre Bagus Saputra.

${ }^{12}$ Bambang Sadono,Ali Lubab, Zaenal Arifin.
} 
but also communally as a group As a way to harmonize the interests and roles of individual individuals with the interests of the community. Furthermore, in Law no. 13 Year 2003 Article 86 paragraph (1) states that each laborer has the proper to get assurance for:

a. Occupational Health and Safety;

b. Morals and decency; and

c. Treatment in agreement with human respect and values and devout values.

Prior to the existence of the Manpower Law no. 13 Year 2003, laws and regulations that provide legal protection to workers are very minimal. Although it is recognized that the legal protection arrangements in the Manpower Act No. 13 Year 2003 have not answered all the problems that are so wide and complex, it is at slightest one step advance and is anticipated to supply lawful security for specialists, particularly those concerning the terms of business. - working conditions, working conditions as well as social security and other work assurance and can be used as a reference within the settlement of mechanical relations debate. ${ }^{13}$

The employment agreement for a new employee is very important because it contains very basic statements that contain the agreement of the parties to follow all agreements. In a work agreement letter between the company and female workers, it contains at least three main points regarding the protection of female workers, the three main points are: First, protection that is protective, protective protection aims to provide protection for women's reproductive functions. The form is in the form of giving rest during menstruation, pregnancy, childbirth or miscarriage. In addition, by providing opportunities to breastfeed children during working hours. Protective protection is also realized in the form of night work arrangements for women, provision of shuttle vehicles and additional nutritious food and drinks. Equally important is the protection of the safety and decency of the workers. ${ }^{14}$

Second, corrective protection, in the form of monitoring the possibility of a ban in the form of termination of employment (PHK) on the grounds of pregnancy, childbirth, miscarriage or breastfeeding. Third, protection regarding equality in obtaining employment opportunities and treatment without discrimination is realized in the form of a prohibition on discrimination in terms of wages, employment and position. In this case, employers may not discriminate between men and women in terms of wages, promotions and rights to social security. ${ }^{15}$

Furthermore, if referring to the Law of the Republic of Indonesia No. 13 Year 2003, then the contents of the work agreement between the company and the female worker, the minimum content of the work agreement includes:

a. Protection agreement in the case of night work for female workers (23.00 to 07.00). In its implementation, there are still companies that do not provide nutritious food and drinks but are replaced with money even though the provisions must not be replaced with money;

b. Protection agreement for female workers who are not required to work on the first and second day of menstruation with full wages. In practice, more people do not exercise their rights on the grounds that they do not get attendance premiums;

c. Maternity leave protection agreement for 1.5 months before the time of giving birth and 1.5 months after giving birth with full wages. It turns out that in practice there are still companies that do not pay wages in full; and

\footnotetext{
${ }^{13}$ Bill Clinton, 'Perlindungan Hukum Terhadap Hak Tenaga Kerja Wanita Di PT. Beka Engineering Pangkalan Kerinci', JOM Fakultas Hukum, 3.2 (2016), 2.

${ }^{14}$ Joupy Mambu, 'Aspek Perlindungan Hukum Terhadap Pekerja Wanita (Menurut Undnag-Undang Ketenagakerjaan)', Jurnal De Jure, Jurnal Syariah Dan Hukum, 2.2 (2010), 45.

${ }^{15}$ Joupy Mambu.
} 
d. Providing openings for female laborers whose children are still breastfeeding to breastfeed their children is as it were successful for those found near to the company.

Worker/labor is any person who works by receiving wages or other forms of remuneration. This is in accordance with Law No. 13 Year 2003, Article 1 concerning general provisions regarding workers. Women, both as citizens and as workers who take part in development, have the same rights, obligations and opportunities as men in all areas of the nation's life in all development activities. Likewise, if female workers who work in companies or factories or who sell their services or labor, must receive good protection for safety, health, and morality, upkeep of work resolve and treatment in understanding with human respect and devout ethics. 13 of 2003 there are 2 chapters that accommodate the protection of female workers, namely chapter III on equal opportunity and treatment. As well as chapter X paragraph 3 which fully discusses female workers. To find out more, how deep is Law no. 13 of 2003 regulates the protection of female workers, so the following is described all the articles concerning female workers. ${ }^{16}$

For pregnant female workers, protected by Law no. 13 Year 2003 Article 82 paragraphs (2) and (3) which states:

a. Female workers/labors are entitled to a break of 1.5 (one and a half) months some time recently giving birth to a child and 1.5 (one and a half) months after giving birth agreeing to the calculation of the obstetrician or birthing assistant;

b. Female workers/laborers who experience an abortion are entitled to a 1.5 (one and a half) month break or according to a certificate from an obstetrician or midwife.

As for breastfeeding, it is regulated in Article 83 of Law no. 13 Year 2003, namely: Female workers/labors whose children are still breastfeeding must be given appropriate opportunities to breastfeed their children if it must be done during working hours. What is meant by proper opportunity in this Article is the length of time given to female workers/ laborers to breastfeed their babies by taking into account the availability of a place that is in accordance with the conditions and capabilities of the company, which is regulated in regulations or collective labor agreements.

\section{The Perspective of Islamic Law regarding Female Workers}

Allah Ta'ala created male and female with different characteristics. By nature (sunnatullah), men have strong muscles, the ability to do heavy work, never give up, be patient and others. Suitable with tiring work and in accordance with his duties, namely to support his family properly. While the forms of difficulties experienced by women are: Conceiving, giving birth, breastfeeding, nurturing and educating children, and menstruation which results in an unstable condition, decreased appetite, dizziness, pain in the stomach and weakened thinking power. When she gave birth to her baby, she had to rest, wait until the day or day she was sick and felt so many complaints, but she had to bear it too. Plus the period of breastfeeding and parenting that took two years. During this time, a baby enjoys the food and nutrients eaten by the mother, thereby reducing her stamina. ${ }^{17}$

Therefore, Islam requires women to do jobs/careers that do not conflict with their feminine nature and do not impede their rights at work, except in aspects that can maintain their honor, dignity and calm and protect them from harassment and dumping. Islam has guaranteed a happy and peaceful life for women and has not made it necessary to work outside the home under normal conditions. Islam puts the burden on the shoulders of men

\footnotetext{
${ }^{16}$ Joupy Mambu.

${ }^{17}$ Miftahul Rohmah.
} 
to work hard and work hard to support their families. So, while the woman is not or has not been married and is not in the waiting period ('iddah) because her husband is divorced or left to die, then her maintenance is borne on the shoulders of her parents or other children, based on the details mentioned by the scholars of fiqh (Miftahul Rohmah, Thesis of the Syari'ah Faculty of the State Islamic University of Sulthan Thaha Saifuddin Jambi 2019/2020).

The Qur'an has provided information to humans to provide special rights for female workers. Indeed, explicitly, we will not find verses in the Qur'an that mention the word 'special rights for female workers'. However, implicitly, there are general arguments based on the verses of the Qur'an that can be used as a basis for granting this right. Some of the special rights of female workers which are implicitly communicated in Islamic teachings, including the following:

a. Wearing Muslim clothes

Islam commands Muslim women to wear the hijab when leaving the house or meeting a man who is not their mahram. The command is based on the word of Allah Subhanahu wa-ta'ala QS. Al-Azhab (33): 59. which means:

"O Muhammad, say to your spouses, your girls, and the spouses of the devotees; let them extend out their headscarves all over their bodies. That's so that they are simple to distinguish, hence they are not aggravated. And Allah is Most Excusing, Most Kind."

b. Salary equivalent to male workers

Allah Subhanahu wa-ta'ala says in QS. Al-Mu'minun (23): 40 which means:

"And whoever does righteous deeds, both male and female, while he is in a state of faith, they will enter Paradise, they will be provided with sustenance in it without reckoning."

This verse is proof of the justice of Allah Subhanahu wa-ta'ala to His servants regardless of gender differences. Whoever he is, whether from among women or men, will get the same favors from Allah Subhanahu wa-ta'ala in the hereafter if they both believe and do good deeds. One form of justice is to provide equal wages for male workers and female workers. Some companies provide lower wages for female workers, which are usually only half of the wages for male workers, even though the type, time, and risk of the work are the same. This discriminatory policy is very inhumane and contrary to Islamic teachings. Giving equal wages is the right of female workers that must be fulfilled by the company. In fact, it would be better if female workers earn more than male workers, considering that women are physically weaker than men.

c. Pregnant

Having children is a human right as well as the desire of every human being, including women. Because the baby can cool the view and reassure the feelings of his parents. In addition, children are also a priceless treasure that can be useful for both parents in this world and in the hereafter. Therefore, the company is obliged to guarantee the human rights of women workers to be able to conceive their own children, by not taking actions that harm the women workers, as well as the children they are carrying.

d. Menstrual leave, pregnancy and postpartum

Menstruation is a monthly 'guest' which is generally uncomfortable for women, because it is hindered from many activities, including prayer and fasting activities. For some women, menstruation causes excruciating pain, so that they have to take 
medication/herbs to relieve menstrual pain. Female workers who experience menstruation are entitled to leave for the sake of their safety and physical security. Moreover, some female workers cannot concentrate on their duties when their monthly 'guests' come. The Qur'an also hints that they should be given a dispensation during menstruation. So is the problem of getting pregnant. Pregnancy is an amazing phenomenon that is felt by women. They feel happy and proud of the presence of the fetus in the womb. The feelings of pregnant women sparkle when they know that the result of an affectionate relationship with their beloved husband will soon be born as a cute and adorable little baby.

e. Childcare facilities

Women are very much needed by their children, especially when the baby is still a baby or toddler. Mothers must breastfeed their babies so that the children grow up healthy and strong. Therefore, the company strives to provide representative child care facilities in the office/work environment. With the existence of child care centers that are not allowed to be entered by adult men, female employees can easily breastfeed their children while working. When the mother carries out her duties, the child is temporarily taken care of by a baby sitter who is paid by the company, or paid for by each employee. This facility makes the bond between mother and baby strong even though the mother is active as a career woman. Meanwhile in Indonesia, facilities like this are neglected.

\section{The Legal Protection for Female Workers in the Perspective of Islamic Law and Law No. 11 Year 2020 on Job Creation}

In this discussion, we begin by sorting out the notions between the state, politics and law. Because these three elements are a system that cannot be separated. Although the definitions and understandings of the three elements are not discussed in detail, at least some brief definitions from the experts that will be reviewed below can describe the relationship between one element and another. ${ }^{18}$ The state is characterized as an organization in an range that has the most noteworthy legitimate control and is complied by its individuals, where the control in address is the capacity of a individual or gather to impact the behavior of another individual or gather, in accordance with the wishes of the perpetrators. While politics is an attempt to achieve a good life. Politics is also defined as a strategy or effort to seize and maintain power. $n$ the interim, to see the definition of law, numerous specialists translate it, this appears that it is genuine that the law is troublesome to characterize. Be that as it may, in common, law can be translated as a set of directions made by the specialists with the point of directing the order of social life which has the characteristics of commanding and prohibiting and has a coercive nature by imposing punitive sanctions for those who violate it. ${ }^{19}$

The work copyright law as a legal rule has caused many pros and cons in society. but basically the Omnibus Law or the Job Creation Law is not to side with the interests of entrepreneurs but to increase economic growth in Indonesia, this opinion was expressed by the Minister of Law and Human Rights (Menkumham) Yasonna H. Laoly. Many things are taken into consideration by the government to ratify the Omnibus Law on Job Creation. Unemployment in Indonesia continues to increase and has reached seven million people is

\footnotetext{
${ }^{18}$ Ismail Koto, 'Hate Speech and Hoax Ditinjau Dari Undang-Undang Ite Dan Hukum Islam', SOSEK: Jurnal Sosial Dan Ekonomi, 2.1 (2021), 48-56.

${ }^{19}$ Rahmat. Ramadhani, 'Peran Politik Terhadap Pembangunan Hukum Agraria Nasional', Sosek: Jurnal Sosial Dan Ekonomi, 1.1 (2020).
} 
one of the factors that pushed the Omnibus Law on Job Creation to be ratified. To eliminate overlapping laws and regulations that are similar or conflicting with each other to be rearranged is also one of the objectives of the draft Law. Act on the Omnibus Law on Job Creation. In this case, we can see that the government's actions at one time will be carried out against dozens of laws. The DPR-RI through the $7^{\text {th }}$ plenary meeting on October 5, 2020 ratified the draft Omnibus Law on Job Creation into Law No. 11 Year 2020 on Job Creation (Ciptature Law or CK Law). Creating jobs, increasing foreign investment in the country by reducing the terms and regulations for business permits and land acquisition are one of the objectives of the ratification of Law Number 11 Year 2020 on Job Creation which contains 1,187 pages. ${ }^{20}$

In Article 3 of the Employment Creation Law Number 11 Year 2020 it is stated that this law aims to create job opportunities for all Indonesian people as widely and evenly as possible by: ${ }^{21}$

1. MSMEs and cooperatives have easy access to empowerment and protection;

2. Improved investment ecosystem;

3. Facilitate Business Opening;

4. Improved worker welfare;

5. The government becomes the center of investment;

6. Accelerated National strategic projects.

Other benefits with the passing of the Job Creation Act are:

1. Align and Simplify licensing and regulations;

2. Achievement of quality investment by increasing economic growth;

3. Quality jobs will be created and workers' welfare will be guaranteed on an ongoing basis;

4. Economic value and people's standard of living have increased;

5. Micro-enterprises have increased productivity, so that Indonesia is able to compete in the world.

Omnibus comes from the Latin (omnis = all; many). Law in English is "law". It can be concluded, Omnibus Law is a law that regulates all things in all fields. According to experts, the Omnibus Law is an umbrella law. The Umbrella Law or often called the "UU Principal" is a law against sectoral laws with certain legal issues. The Minister of Agrarian and Spatial Planning, Sofyan Djalil, is of the opinion that laws that can improve the number of laws that are considered to hinder the ease of doing business and are contradictory so far have been appropriate by applying the concept of the Omnibus Law. This concept can be an appropriate means as a way out of problems in the economic sector because so far the complexity of laws but contradicting each other has been a factor inhibiting the process of economic growth in Indonesia., for example Anglo-Saxion and also the United States when making regulations. The concept of Omnibus Law in making regulations is to amend many laws at the same time and make them into one new law. ${ }^{22}$

Among the 11 clusters in the Job Creation Bill, employment is one of the things regulated in it. There are three laws that will be amended through the Job Creation Act, namely: First Law 13/2003 concerning Manpower, Second Law 40/2004 concerning the National Social Security System, and Third Law 24/2011 concerning Social Security Administering Bodies. The government seeks to harmonize the law so that it is able to

\footnotetext{
${ }^{20}$ J.S Catur, 'Perlindungan Hukum Terhadap Kesejahteraan Pekerja Melalui Undang-Undang Nomor 11 Tahun 2020 Tentang Cipta Kerja', Jurnal Lex Specialis, 1.2 (2020), 12.

${ }^{21}$ Catur.

${ }^{22}$ Catur.
} 
provide space for investors without causing losses as well as avoiding overlapping regulations. $^{23}$

The protection of female workers has been regulated by law and several regulations, but regarding its implementation there are still many employers who have not implemented it such as not giving leave on the first and second days, not giving holidays after giving birth, and also not providing a special room to rest. for female workers who are sick during their menstruation period, so that the impact is felt by the female workers. In practice, the legal protection for female workers provided by UD. Tiga Topi has not fully fulfilled the formulation contained in Law number 13 of 2003 concerning employment. Some legal protections that are not implemented by UD. Three Hats, one of which was when a female worker asked for two days of leave at the start of her period because she felt sick. In accordance with Law No. 13 of 2003 article 81 paragraph 1, that "Women workers/laborers who feel pain during menstruation and notify employers are not obliged to work on the first and second days of menstruation." 24

The following are some changes related to female workers in the Manpower Act with the Omnibus Law. In Article 153 paragraph 1 letter e of the Manpower Law it is stated that female workers may not be subject to termination of employment on the grounds of pregnancy, childbirth, miscarriage, or breastfeeding their baby, the article is discussed in the Omnibus Law but in no way changes the substance of protecting the rights of women workers in the Manpower Law. . Furthermore, according to Article 185 of the Manpower Act, it says that punishing violations of Article 82 which is a criminal offense punishable by imprisonment for a minimum of 1 (one) year and a maximum of 4 (four) years and/or a fine of at least Rp. 100,000,000,-( one hundred million Rupiah) and a maximum of Rp. 400,000,000 (four hundred million Rupiah). The above is also discussed in the Copyright Act, but also does not change the substance of the rules.

Based on the description above, it is clear that Law Number 11 Year 2020 on Job Creation does not change the substance of providing protection for the rights of women workers as previously regulated in Law Number 13 Year 2003 on Manpower. The protections for female workers as referred to in the previous labor law are still in effect and are not discussed at all in Law Number 11 Year 2020 on Work Creation. is not true and false. The article that underwent changes related to the protection of women workers did not at all change the substance of the protection of female workers as previously regulated through Law Number 13 Year 2003 on Manpower. Although in reality the enforcement of women's rights must still be given great attention because it is often neglected, especially in the field of small and micro enterprises. So that in the process of discussing the revision of Law Number 13 of 2003 concerning Manpower in Law Number 11 Year 2020 on Job Creation, it should also discuss the provision of affirmation of sanctions for business actors (including small and micro businesses) that do not provide women's rights. as stipulated in the existing legal rules.

\section{CONCLUSION}

Law Number 11 Year 2020 on Job Creation in no way changes the substance of providing protection for the rights of women workers as previously regulated in Law Number 13 Year 2003 on Manpower. The protections for female workers as referred to in the previous labor law are still in effect and are not discussed at all in Law Number 11 Year 2020 on Work Creation is wrong. The article which was amended related to the protection of

\footnotetext{
${ }^{23}$ Catur.

${ }^{24}$ Baagil, 'Analisis Yuridis Pelaksanaan Perlindungan Hukum Terhadap Hak Tenaga Kerja Perempuan', Jurnal Dinamika, 26.9 (2020), 20.
} 
female workers did not change the substance of the protection of female workers as previously regulated through Law Number 13 Year 2003 on Manpower. Although in reality the enforcement of women's rights must still be given great attention because it is often neglected, especially in the field of small and micro enterprises. So that in the process of discussing the revision of Law Number 13 Year 2003 on Manpower in Law Number 11 Year 2020 on Job Creation, it should also discuss the provision of affirmation of sanctions for business actors (including small and micro businesses) that do not provide women's rights. as stipulated in the existing laws. The Qur'an has been explained that people need to provide special rights for female workers. Explicitly, there is no verses in the Qur'an that mentioned the word 'special rights for female workers'. However, implicitly, there were general arguments based on the verses in the Qur'an that could be used as a basis for granting this right. Some of the special rights of female workers were implicitly communicated in Islamic teachings.

\section{REFERENCES}

Andre Bagus Saputra. (2021). Perlindungan Pekerja Perempuan Masa Pandemi Dalam Prespektif CEDW. Rubrik Opini, Hukum Laut Internasional LEGALTALK, Buletin Hukum, 2(7), 3

Baagil. (2020). Analisis Yuridis Pelaksanaan Perlindungan Hukum Terhadap Hak Tenaga Kerja Perempuan. Jurnal Dinamika, 26(9)

Bambang Sadono, Ali Lubab, Zaenal Arifin, Kadi Sukarna. (2020). Kedudukan Komisi Pemberantasan Korupsi Dalam Sistem Ketatanegaraan Di Indonesia. USM LwReview, 3(2), 263

Bill Clinton. (2016). Perlindungan Hukum Terhadap Hak Tenaga Kerja Wanita Di PT. Beka Engineering Pangkalan Kerinci. JOM Fakultas Hukum, 3(2), 2

Catur, J.S. (2020). Perlindungan Hukum Terhadap Kesejahteraan Pekerja Melalui UndangUndang Nomor 11 Tahun 2020 Tentang Cipta Kerja', Jurnal Lex Specialis, 1(2), 12

Christina Aryani. (2021). Reformulasi Sistem Pembentukan Peraturan Perundang-Undangan Melalui Penerapan Omnibus Law. Jurnal USM Law Review, 4(1), 29

Febri Jaya. (2020). Perlindungan Hak-Hak Pekerja Perempuan Pasca Revisi Undang-Undang Ketenagakerjaan Dalam Omnibus Law. Jurnal Kertha Semaya, 8(12), 86

Harisman, H. (2020). Community Rights Facing Criminal Law in a Human Rights Perspective. Randwick International of Social Science Journal, 1(2), 264-270. https://doi.org/10.47175/rissj.v1i2.51

Ismail Koto. (2021). Hate Speech Dan Hoax Ditinjau Dari Undang-Undang Ite Dan Hukum Islam', SOSEK: Jurnal Sosial Dan Ekonomi, 2(1), 48-56

Joupy Mambu. (2010). Aspek Perlindungan Hukum Terhadap Pekerja Wanita (Menurut Undnag-Undang Ketenagakerjaan). Jurnal De Jure, Jurnal Syariah Dan Hukum. 2(2), 45

Lalu Husni. (2004). Penyelesaian Perselisihan Hubungan Industrial Melalui Pengadilan Dan Di Luar Pengadilan. Jakarta: PT. Raja Grafindo

Marzuki, P. M. (2011). Penelitian Hukum. Jakarta: Kencana

Miftahul Rohmah. (2020). Perlindungan Hukum Terhadap Tenaga Kerja Perempuanmenurut Undang-Undang Nomor 13 Tahun 2003 Tentang Ketenagakerjaan Dan Hukum Islam', Fakultas Syari'ah Universitas Islam Negeri Sulthan Thaha Saifuddin Jambi

Ramadhani, Rahmat. (2020). Peran Politik Terhadap Pembangunan Hukum Agraria Nasional', Sosek: Jurnal Sosial Dan Ekonomi, 1.1

Siregar, T. A. (2005). Metodologi Penelitian Hukum Penulisan Skripsi. Medan: Pustaka Bangsa Press. Medan: Pustaka Bangsa Press

Soekanto, S. and S. M. (2003). Penelitian Hukum Normatif. Suatu Tinjauan Singkat. Jakarta: Raja Grafindo Persada

Zahro, Nurhalimatuz, Faisal Akbar Nasution, Mirza Nasution, and Chairul Bariah. (2021). Proyeksi Konstitusional Rekrutmen Hakim Agung Oleh Komisi Yudisial', Jurnal USM Law Review, 4(1), 87 